\title{
MAXIMIZING SUGAR BEET YIELDS WITH DECREASING MINERAL FERTILIZATION POLLUTION
}

\author{
SEADH S.E.* \\ Agronomy Department, Faculty of Agriculture, Mansoura University, Egypt. \\ *Corresponding Author: Email- seseadh04@mans.edu.eg
}

Received: November 05, 2012; Accepted: November 20, 2012

\begin{abstract}
In order to increase sugar beet productivity beside decreasing mineral fertilization pollution two field experiments were carried out at El-Garayda Village, Bialla Center, Kafr El-Sheikh Governorate during 2010/2011 and 2011/2012 seasons. This study aimed to determine the effect of nitrogen, phosphorus and potassium (NPK) fertilizers levels (100, 75 and $50 \%$ decrease from recommended dose) and foliar fertilization treatments as follows; control treatment, spraying with water, Melagrow, Amino-Power and Melagrow + AminoPower on sugar beet (Beta vulgaris L.) cv. Gloria growth, yield components, yield and quality parameters. A strip plot design with four replications was used. The results showed that increasing NPK levels from 50 up to $100 \%$ of the recommended dose significantly affected all studied characters in both seasons. Application $100 \%$ of the recommended dose of NPK ( $80 \mathrm{~kg} \mathrm{~N}+30 \mathrm{~kg} \mathrm{P} \mathrm{O}_{5}+48 \mathrm{~kg} \mathrm{~K} 2 \mathrm{O} / \mathrm{fed}$ ) was the most effective treatment on yield. Foliar fertilization treatments significantly affected all studied characters, except purity \% in both seasons. Spraying with Melagrow + Amino-Power solution produced highest values of all studied characters. Maximum values of sugar beet growth, yields and its components could be achieved by fertilizing with $100 \%$ of the recommended dose of NPK and spraying with Melagrow + Amino-Power. It can be recommended that mineral fertilization with $75 \%$ of the recommended dose of NPK and spraying with Melagrow + Amino-Power, which exceeded yields and root quality upon mineral fertilizing with $100 \%$ of the recommended dose of NPK + without spraying, and also possibility to reduce agriculture costs and mineral fertilization pollution.
\end{abstract}

Keywords- Sugar beet, NPK levels, mineral fertilization pollution, foliar fertilization, yields, quality

Citation: Seadh S.E. (2012) Maximizing Sugar Beet Yields with Decreasing Mineral Fertilization Pollution. International Journal of Agriculture Sciences, ISSN: 0975-3710 \& E-ISSN: 0975-9107, Volume 4, Issue 7, pp-293-298.

Copyright: Copyright@2012 Seadh S.E. This is an open-access article distributed under the terms of the Creative Commons Attribution License, which permits unrestricted use, distribution and reproduction in any medium, provided the original author and source are credited.

\section{Introduction}

Mineral synthetic fertilizers are composed mostly of nitrogen, phosphorous and potassium, which produce the greatest impact on plant growth. Although these fertilizers may produce impressively quick results in field where growth improved, the excessive and uncontrolled use of these synthetic compounds can lead to fertilizer pollution. The excessive use of synthetic fertilizer may increase yields in the short term and cause serious water pollution and harm to humans.

Moreover in Egypt, there was a gap between sugar consumption and production due to steady increases in the country population and average consumption of sugar beside limited cultivated area. Increasing sugar crops cultivated area and sugar production per unit area are considered the important national target to minimize the gab between sugar consumption and production. Improvement of sugar beet productivity can be achieved through many factors such as fertilization management and foliar fertilization.

NPK fertilization is among the vital factors affecting growth, yield and quality of sugar beet, thus application the suitable rates of nitrogen, phosphorus and potassium one of the favorable factors for increasing sugar beet productivity and quality. The proper fertilization reference can be given only based on the soil fertility. It must be determining optimum nitrogen rate, which produce the maximum root, sugar yields and quality parameters. In this respect, $[10,13,15,17,22]$ stated that raising nitrogen fertilizer rates up to 90 $\mathrm{kg} \mathrm{N} / \mathrm{fed}$ increased all yield components and root, sugar yields significantly. Whereas, highest quality parameters values were obtained from the lowest nitrogen rate. $[1,8,19,20,23,24]$ concluded that increasing nitrogen fertilizer levels up to $125 \mathrm{~kg} \mathrm{~N} / \mathrm{fed}$ under newly reclaimed soil conditions significantly increased yield components, root and sugar yields. While, remarkable reduction were found on quality traits. Phosphorus fertilization is an essential nutrient to sugar beet production [7]. Sims and Smith [25] reported that root yield significantly less in the control treatment $\left(0 \mathrm{~kg} \mathrm{P}_{2} \mathrm{O}_{5} / \mathrm{ha}\right)$ compared to apply others (15,30 and $45 \mathrm{~kg} \mathrm{P}_{2} \mathrm{O}_{5} / \mathrm{ha}$ ). Marinkovic $\mathrm{B}$., et al [16] showed that by increasing amounts of phosphorus from 50 to 100 and $150 \mathrm{~kg} \mathrm{P}_{2} \mathrm{O}_{5} / \mathrm{ha}$, root and sugar yields were increased. Potassium plays an important roles in photosynthesis, protein synthesis, translocation of assimilates as well as increasing plant growth and yield. In this concern, Amer M.A., et al [3] found that adding potassium up to $90 \mathrm{~kg} \mathrm{~K} \mathrm{~K}_{2} \mathrm{O} / \mathrm{fed}$ resulted a significant 
increase in root and sugar yields/fed, TSS, sucrose and purity percentages. Gobarah Mirvat E., et al [9] stated that application potassium fertilizer at the rate of $114 \mathrm{~kg} \mathrm{~K} \mathrm{~K}_{2} \mathrm{O} /$ ha significantly increased root weight and dimensions, sucrose and purity percentages as well as root, top and sugar yield. Potassium uptake is much affected by nitrogen level and in most cases, potassium is more effective at higher nitrogen level, which is the case especially to modern high yielding varieties. In this regard, Abdel-Motagally and Attia [1] and Seadh S.E., et al [23] concluded that application the highest level of $\mathrm{NK}(125 \mathrm{~kg} \mathrm{~N}+72 \mathrm{~kg} \mathrm{~K}$ O/fed) improved root and sugar yields as well as sugar beet grown in a sandy soil. Marinkovic B., et al [16] concluded that the optimal fertilization variant for the root yield was $100 \mathrm{~kg} \mathrm{~N}+50 \mathrm{~kg} \mathrm{P}_{2} \mathrm{O}_{5}+50 \mathrm{~kg} \mathrm{~K} 2 \mathrm{O} / \mathrm{ha}$. While, the optimal fertilization variant for the quality and sugar yield was $50 \mathrm{~kg} \mathrm{~N}$ $+50 \mathrm{~kg} \mathrm{P}_{2} \mathrm{O}_{5}+50 \mathrm{~kg} \mathrm{~K} 2 \mathrm{O} / \mathrm{ha}$.

Foliar fertilization of nutrients is considering one of various techniques to improve fertilizer efficiency in order to increase productivity and improve quality of crop product [21]. This procedure can improve nutrient utilization and lower environmental pollution through reducing the amount of fertilizer added to soil [2]. Natural plant growth takes place through regular photosynthesis. The foliar application with Melagrow as a natural plant growth promoter for different crops was a great importance which promotes growth, increases yield and improves quality due to its contain phosphorus, potassium, boron and brassinolides and combined effects of growth regulators such as oxen, cytokines, gibberellins, ethylene and hydrogen cyanamid [4]. Amino acids is a well known biostimulant which has positive effects on growth, yield and significantly reduces the injuries caused by abiotic stresses [14]. Tugnoli and Bettini [27] concluded that use of amino acids and biostimulants as foliar spraying makes it possible to quickly overcome the nutritional and environmental deficiencies that arise during the crop growth cycle. Diána and Győri [6] stated that foliar fertilization significantly increased root and the sugar yields, while the quality parameters have not changed. Further, Grzebisz W., et al [12] found that root yield had increased by $31.6 \%$ and $22.1 \%$ for the $\mathrm{NPK}+\mathrm{Mi}$ (spraying with multi-microelement fertilizer composed of cations) and NPK + MiB (spraying with multi-microelement fertilizer plus boron) treatments, respectively as compared with NPK (plot fertilized only with NPK) treatment. Almost the same degree of increase was noted for yield of recoverable sugar.

Therefore, this experiment aimed to study the response of sugar beet $\mathrm{Cv}$. Gloria to decreasing different NPK rates and compensate this reduction in NPK rates with foliar fertilization treatments to achieve maximum productivity and quality of sugar beet in a same time decreasing mineral fertilization pollution.

\section{Materials and Methods}

Two field experiments were carried out at El-Garayda Village, Bialla Center, Kafr El-Sheikh Governorate during 2010/2011 and $2011 / 2012$ seasons. The main objective of this study was to determine the effect of nitrogen, phosphorus and potassium (NPK) fertilizers levels and foliar fertilization treatments on sugar beet (Beta vulgaris L.) cv. Gloria growth, yield and its components and quality parameters.

The experiments were laid-out in strip plot design with four replications. The vertical plots were assigned with three levels of NPK fertilizers as follows: a- $100 \%$ of the recommended level $(80 \mathrm{~kg} \mathrm{~N}+$ $\left.30 \mathrm{~kg} \mathrm{P} \mathrm{O}_{5}+48 \mathrm{~kg} \mathrm{~K} \mathrm{O}_{2} / \mathrm{fed}\right) . \mathrm{b}-75 \%$ of the recommended level (60 $\left.\mathrm{kg} \mathrm{N}+22.5 \mathrm{~kg} \mathrm{P}_{2} \mathrm{O}_{5}+36 \mathrm{~kg} \mathrm{~K} \mathrm{O}_{2} / \mathrm{fed}\right) . \mathrm{c}-50 \%$ of the recommended level (40 kg N + $15 \mathrm{~kg} \mathrm{P} \mathrm{O}_{5}+24 \mathrm{~kg} \mathrm{~K}$ O/fed). Nitrogen and potassium fertilizers in the forms of urea $(46 \% \mathrm{~N})$ and potassium sulphate $\left(48 \% \mathrm{~K}_{2} \mathrm{O}\right)$, respectively were applied as a side-dressing in two equal portions, one half after thinning ( 35 days from sowing) and the other before the third irrigation (70 days from sowing). Calcium superphosphate $\left(15.5 \% \mathrm{P}_{2} \mathrm{O}_{5}\right)$ was applied during soil preparation.

The horizontal plots were occupied with five foliar fertilization treatments as follows: 1- Without spraying (control treatment). 2- Spraying with irrigation water. 3-Spraying with Melagrow at the rate of 10 g Melagrow/200 liter water/fed). 4. Spraying with Amino-Power at the rate of $100 \mathrm{ml} / 200$ liter water/fed. 5- Spraying with Melagrow at the rate of $10 \mathrm{~g}$ Melagrow/200 liter water/fed + Amino-Power at the rate of $100 \mathrm{ml} / 200$ liter water/fed. Spraying was conducted by hand sprayer twice at the aforementioned rates after 50 and 70 days from sowing.

Melagrow is produced by Green India Co., and obtained from Gaara Foundation for Import and Export. Melagrow is considering as natural growth promoter extracted from pollen of cabbage flowers. Melagrow is combined effects of many growth regulators such as oxen, cytokines, gibberellins, ethylene and hydrogen cyanamid. The chemical composition of Melagrow is $20 \%$ phosphorus, $10 \%$ potassium, $3 \%$ boron and $0.2 \%$ brassinolide. Natural brassinolides $(0.2 \%)$ is natural plant growth promoter for growth, yield increases and improves quality.

Amino-Power ${ }^{\circledR}$ was obtained from Union For Agriculture Development $\mathrm{Co}$. Amino-Power is consider also as natural growth promoter, which contain free amino acids in a form of Levogire "L-Amino Acids" (Glycin, Seriocin, Glutamic, Valin, Broline, Hydroxy broline, Methionine iso lucin, lucin, Phenyl, Alanine, Serine, Asparatic, Arginine, Hydroxy Lysine and Hestedine) in addition microelements (Fe 1500 ppm, Zn 500 ppm and Mn 500 ppm) and citric acid (3.5\% potassium citrate).

The soil was clay texture with an electrical conductivity (EC) of 1.65 $\mathrm{dS} / \mathrm{m}$ and a $\mathrm{pH}$ of 7.88 . Each experimental basic unit included 5 ridges, each of $60 \mathrm{~cm}$ apart and $3.5 \mathrm{~m}$ long, comprising an area of $10.5 \mathrm{~m}^{2}$ (1/400 fed). The preceding summer crop was rice (Oryza sativa L.) in both seasons.

Experiments were sown on September $15^{\text {th }}$ and $18^{\text {th }}$ in the first and second seasons, respectively. Sugar beet was hand sown 3-5 balls/hill using dry sowing method on one side of the ridge in hills $20 \mathrm{~cm}$ apart. Plants were thinned to one plant/hill (35000 plants/ fed) at the age of 35 days from planting. The recommended agricultural practices for growing sugar beet were followed except the factors under study.

\section{Studied Characters}

\section{A. Growth Characters}

Five guarded plants from the outer ridges of each plot were chosen randomly at 150 days from sowing to determine the following growth characters:

1. Total chlorophyll: Leaf chlorophyll content was assessed by SPAD-502 (Minolta Co. Ltd., Osaka, Japan). 
2. Leaf area/plant $\left(\mathrm{cm}^{2}\right)$. It was determined using Field Portable Leaf Area Meter AM-300 (Bio-Scientific, Ltd., Great Amwell, Herforshire, England).

\section{B. Yield, Yield Components and Quality Characters}

At harvest, five plants were chosen at random from the outer ridges of each plot to determine yield components and quality characters as follows:

1. Foliage fresh weight ( $\mathrm{g} /$ plant).

2. Foliage length $(\mathrm{cm})$.

3. Root fresh weight ( $\mathrm{g} / \mathrm{plant})$.

4. Root length $(\mathrm{cm})$.

5. Root diameter $(\mathrm{cm})$.

6. Total soluble solids (TSS \%) in roots was measured in juice of fresh roots by using Hand Refractometer.

7. Sucrose percentage (\%) was determined Polarimetrically on lead acetate extract of fresh macerated roots according to the method of Carruthers and Oldfield [5].

8. Apparent purity percentage (\%). It was determined as a ratio between sucrose $\%$ and TSS $\%$ of roots as the method outlined by Carruthers and Oldfield [5].

Plants that produced from the two inner ridges of each plot at harvesting time were collected and cleaned, and then roots and tops were separated and weighted in kilograms and converted to estimate:

1. Root yield (t/fed).

2. Top yield (tffed).

3. Sugar yield (t/fad). It was calculated by multiplying root yield by sucrose percentage.

All obtained data were statistically analyzed according to the technique of analysis of variance (ANOVA) for the strip plot design as published by Gomez and Gomez [11], using MSTAT statistical package (MSTAT-C with MGRAPH version 2.10, Crop and Soil Sciences Department, Michigan State University, USA). Least Significant Difference (LSD) method was used to test the differences between treatment means at $5 \%$ level of probability [26].

\section{Results and Discussion}

\section{A. Effect of NPK Levels}

The effect of NPK levels on total chlorophyll, leaf area/plant, foliage fresh weight, foliage length, root fresh weight, root length and diameter [Table-1], TSS, sucrose and apparent purity percentages, root, top and sugar yields [Table-2] was significant in the two growing seasons. It can be stated that growth characters, yields and its components significantly increased as a result of increasing NPK from 50 to 75 and $100 \%$ of the recommended rate and the differences among them were significant in both seasons. Application $100 \%$ of the recommended level of NPK $\left(80 \mathrm{~kg} \mathrm{~N}+30 \mathrm{~kg} \mathrm{P}_{2} \mathrm{O}_{5}+\right.$ $48 \mathrm{~kg} \mathrm{~K} 2 \mathrm{O} / \mathrm{fed}$ ) produced the highest values of growth characters, root, top and sugar yields and its components in both seasons. While, fertilizing beet plants with $75 \%$ of the recommended level of $\mathrm{NPK}\left(60 \mathrm{~kg} \mathrm{~N}+22.5 \mathrm{~kg} \mathrm{P}_{2} \mathrm{O}_{5}+36 \mathrm{~kg} \mathrm{~K}_{2} \mathrm{O} / \mathrm{fed}\right)$ came in the second rank, then using $50 \%$ of the recommended level of NPK $(40 \mathrm{~kg} \mathrm{~N}+$ $15 \mathrm{~kg} \mathrm{P}_{2} \mathrm{O}_{5}+24 \mathrm{~kg} \mathrm{~K} 2 \mathrm{O} / \mathrm{fed}$ ), which resulted in the lowest values of growth characters and yields and its components in both seasons.

The increases in yields and its components as a result of increasing NPK levels can be ascribed to the role of nitrogen in improving vegetative growth through enhancing leaf initiation, color and vigor of the leaf canopy as well as meristematic activity which contribute to the increases in number of cells in addition to cell enlargement. Moreover, nitrogen encourages plants to uptake other elements, enhancing net assimilation rate and activating accumulation of carbohydrates, which translated from leaves to developing roots which in turn enhanced root length, diameter, root fresh weight and finally root and sugar yields per unit area [18]. Also, the role of phosphorus in energy transfer within the plants and in maintaining the structural integrity of the plant cell membranes as well as carbohydrate assimilation and improving plant growth, which was reflected in increasing root dimensions and weight $[7,25]$. Beside, the role of potassium in building up metabolites and activating starch synthetase enzymes and carbohydrates accumulation which transferred from leaves to developing roots consequently enhanced root and chemical constituents [18]. Increasing potassium fertilizer level significantly increased root weight and dimensions, sucrose and purity percentages, root, top and sugar yields $[3,9]$. These results are in coincidence with those stated by $[1,16,23]$.

The optimum means of sucrose and purity percentages were obtained from using $50 \%$ of the recommended level of NPK in both seasons. Whereas, the optimum means of TSS $\%$ were achieved when application $75 \%$ of the recommended level of NPK in the two growing seasons. However, application $100 \%$ of the recommended level of NPK produced the lowest values of all quality parameters in both seasons. The decrease in quality parameters due to excessive nitrogen application can be ascribed to its role in increasing root weight and diameter, tissue water content, increasing nonsucrose substances such as proteins and alpha amino acids, and hence decreasing sucrose content in roots. Raising nitrogen fertilizer levels caused a significant decreases in quality parameters of sugar beet $[10,15,17]$. Furthermore, highest quality parameters values were obtained from the lowest level of nitrogen [16].

\section{B. Foliar Fertilization Treatments Effect}

Foliar fertilization treatments significantly affected total chlorophyll, leaf area/plant, foliage fresh weight, foliage length, root fresh weight, root length and diameter [Table-1], TSS $\%$, sucrose $\%$, root, top and sugar yields [Table-2] in both seasons. It could be observed that spraying sugar beet plants twice after 50 and 70 days from sowing with water, Melagrow, Amino-Power and the mixture of Melagrow + Amino-Power caused a gradual increases in all studied characters compared with without spraying (control treatment) in the two growing seasons. Highest values of all studied characters were obtained as a result of spraying sugar beet plants with the mixture of Melagrow + Amino-Power treatment in both seasons under the environmental conditions of studied region. In addition, spraying sugar beet plants with Amino-Power treatment ranked after previously mentioned treatment, followed by spraying sugar beet plants with Melagrow treatment then spraying sugar beet plants with water in the two growing seasons. On the other wise, the control treatment (without spraying sugar beet plants) 
gave the lowest values of these characters in both seasons.

The desirable effect of spraying sugar beet plants with the mixture of Melagrow + Amino-Power may be ascribed to the role of Melagrow in promotes growth, increases yield and improves quality due to its contains macronutrients (phosphorus and potassium), micronutrients (boron) and natural brassinolides as natural plant growth promoter as well as its combined effects of oxen, cytokines, gibberellins [4]. Furthermore, the role of Amino-Power as natural growth promoter also, which contains free amino acids in a form of Levogire (L-Amino Acids) in addition microelements (Fe, $\mathrm{Zn}$ and $\mathrm{Mn}$ ) and citric acid, which has positive effects on plant growth and yield [14]. Foliar fertilization treatments of sugar beet significantly increased root and sugar yields $[6,12,27]$.

Table 1- Means of total chlorophyll, leaf area/plant, foliage fresh weight, foliage length, root fresh weight, root length and diameter as affected by NPK levels and foliar fertilization treatments and their interaction during 2010/2011 and 2011/2012 seasons.

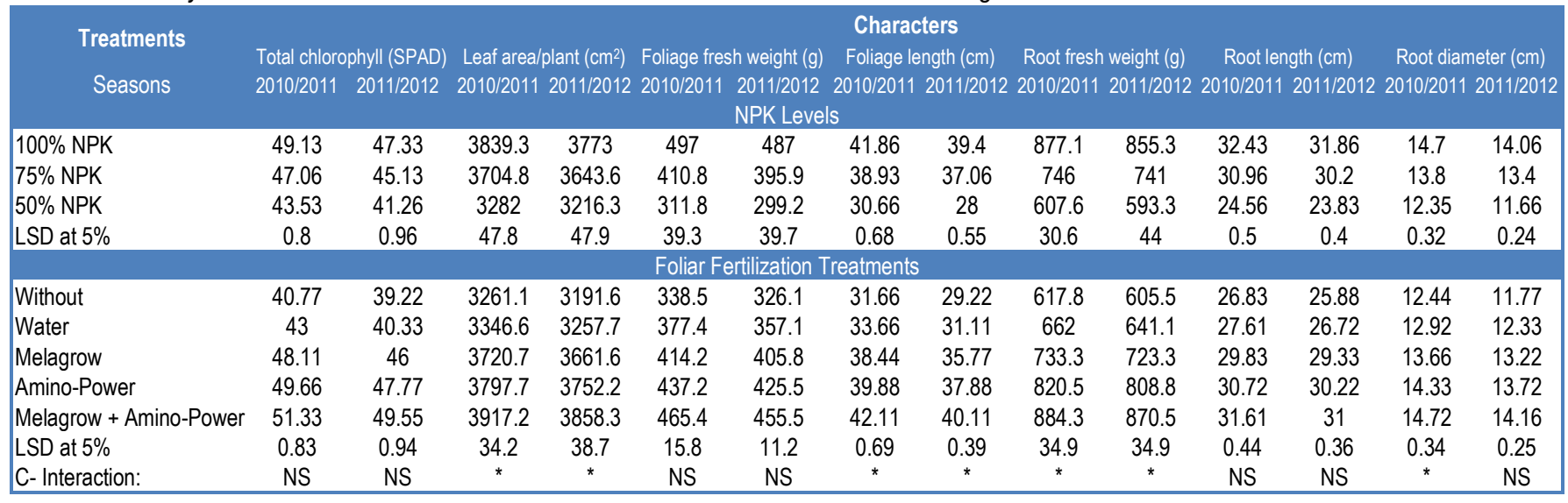

Table 2- Means of total soluble solids (TSS), sucrose and apparent purity percentages, root, top and sugar yields as affected by NPK levels and foliar fertilization treatments and their interaction during 2010/2011 and 2011/2012 seasons.

\begin{tabular}{|c|c|c|c|c|c|c|c|c|c|c|c|c|}
\hline \multirow{3}{*}{$\begin{array}{l}\text { Treatments } \\
\text { Seasons }\end{array}$} & \multicolumn{12}{|c|}{ Characters } \\
\hline & & \multicolumn{2}{|c|}{ Sucrose (\%) } & \multicolumn{2}{|c|}{ Apparent purity (\%) } & \multicolumn{2}{|c|}{ Root yield (t/fed) } & \multicolumn{2}{|c|}{ Top yield (t/fed) } & \multicolumn{2}{|c|}{ Sugar yield (t/fed) } \\
\hline & \multicolumn{2}{|c|}{$\begin{array}{c}150(\%) \\
2010 / 20112011\end{array}$} & $2010 / 2011$ & $2011 / 201$ & \multicolumn{2}{|c|}{$\begin{array}{l}\text { 2010/2011 2011/2012 } \\
\text { NPK Levels }\end{array}$} & \multicolumn{2}{|c|}{$2010 / 20112011 / 2012$} & \multicolumn{2}{|c|}{ 2010/2011 2011/2012 } & \multicolumn{2}{|c|}{$2010 / 20112011 / 2012$} \\
\hline $75 \%$ NPK & 22.56 & 22.11 & 18.04 & 17.78 & 79.99 & 80.45 & 21.778 & 21.387 & 10.645 & 10.4 & 3.935 & 3.809 \\
\hline $50 \%$ NPK & 21.82 & 21.68 & 18.76 & 18.55 & 85.96 & 86.67 & 17.205 & 16.758 & 8.467 & 8.193 & 3.235 & 3.115 \\
\hline LSD at $5 \%$ & 0.28 & 0.27 & 0.15 & 0.2 & 1.3 & 1.29 & 0.787 & 0.685 & 0.704 & 0.695 & 0.137 & 0.142 \\
\hline Without & 21.63 & 21.28 & 17.67 & 17.37 & 81.31 & 81.66 & 18.111 & 17.489 & 8.679 & 8.478 & 3.187 & 3.025 \\
\hline Water & 21.9 & 21.43 & 17.8 & 17.56 & 81.62 & 81.99 & 18.991 & 18.231 & 9.206 & 9.022 & 3.367 & 3.188 \\
\hline Melagrow & 22.2 & 21.78 & 18.11 & 17.87 & 81.74 & 82.09 & 21.737 & 20.856 & 10.353 & 10.05 & 3.919 & 3.711 \\
\hline Amino-Power & 22.36 & 21.96 & 18.31 & 18.04 & 81.84 & 82.15 & 23.431 & 22.417 & 11.349 & 10.983 & 4.269 & 4.025 \\
\hline Melagrow + Amino-Power & 22.61 & 22.2 & 18.48 & 18.22 & 81.93 & 82.19 & 25.333 & 24.308 & 12.282 & 11.772 & 4.657 & 4.408 \\
\hline LSD at $5 \%$ & 0.24 & 0.24 & 0.1 & 0.09 & NS & NS & 0.77 & 0.778 & 0.461 & 0.418 & 0.156 & 0.143 \\
\hline C- Interaction: & NS & NS & * & * & NS & NS & * & * & * & * & * & * \\
\hline
\end{tabular}

\section{Interaction effect}

The interaction between both studied factors (NPK levels $X$ foliar fertilization treatments) had a significant effect on leaf area/plant, foliage length, root fresh weight, sucrose \%, root, top and sugar yields/fed in both seasons and root diameter in the first season only.

The highest values of leaf area/plant [Fig-1], foliage length [Fig-2], root fresh weight [Fig-3], root diameter [Fig-4], root yield/fed [Fig-5], top yield/fed [Fig-6] and sugar yield/fed [Fig-7]were produced from mineral fertilizing sugar beet plants with $100 \%$ of the recommended level of NPK ( $80 \mathrm{~kg} \mathrm{~N}+30 \mathrm{~kg} \mathrm{P}_{2} \mathrm{O}_{5}+48 \mathrm{~kg} \mathrm{~K} 2 \mathrm{O} / \mathrm{fed}$ ) beside spraying with the mixture of Melagrow + Amino-Power. While, the lowest values of these characters were resulted from fertilizing sugar beet plants with $50 \%$ of the recommended level of NPK $(40 \mathrm{~kg} \mathrm{~N}+15$ $\mathrm{kg} \mathrm{P}_{2} \mathrm{O}_{5}+24 \mathrm{~kg} \mathrm{~K} 2 \mathrm{O} / \mathrm{fed}$ ) without spraying treatment (control treat- ment) in both seasons. Whereas, the highest values of sucrose $\%$ [Fig-8] were obtained when mineral fertilizing sugar beet plants with $50 \%$ of the recommended level of NPK in addition spraying with the mixture of Melagrow + Amino-Power, while the lowest values of this character were resulted from fertilizing sugar beet plants with $100 \%$ of the recommended level of NPK without spraying treatment (control treatment) in both. The second best interaction treatment that increased sugar beet yields was mineral fertilizing with $100 \%$ of the recommended level of NPK + spraying with Amino-Power followed by mineral fertilizing with $75 \%$ of the recommended level of NPK + spraying with the mixture of Melagrow + Amino-Power. From obtained results that graphically illustrated in figures 1 through 8, foliar spraying sugar beet plants with the mixture of Melagrow + Amino-Power and fertilizing with $75 \%$ of the recommended level of NPK significantly exceeded the common treatment that most farmer are used (mineral fertilizing with $100 \%$ 
of the recommended level of NPK without spraying treatment) in both seasons.

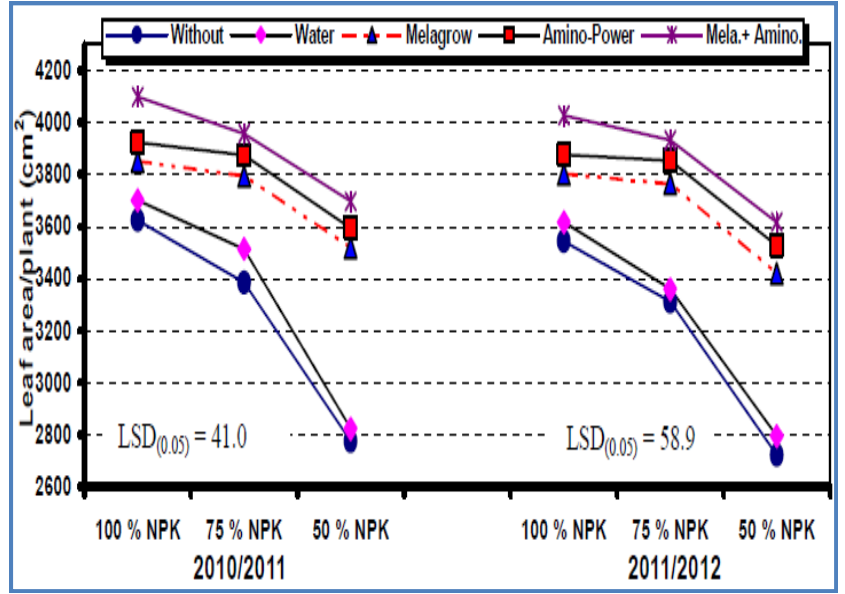

Fig. 1- Leaf area/plant $\left(\mathrm{cm}^{2}\right)$ of sugar beet as affected by the interaction between NPK levels and foliar fertilization treatments during 2010/2011 and 2011/2012 seasons

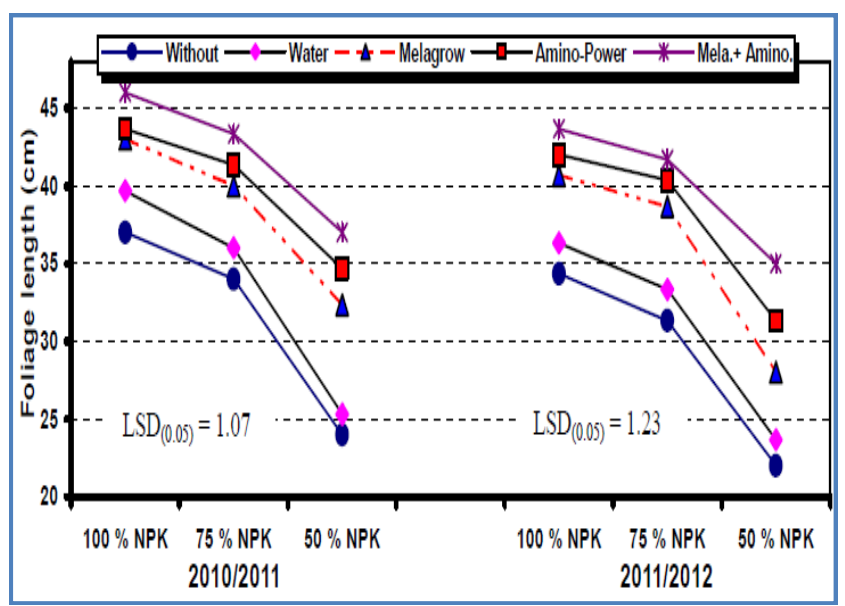

Fig. 2- Foliage length $(\mathrm{cm})$ of sugar beet as affected by the interaction between NPK levels and foliar fertilization treatments during 2010/2011 and 2011/2012 seasons.

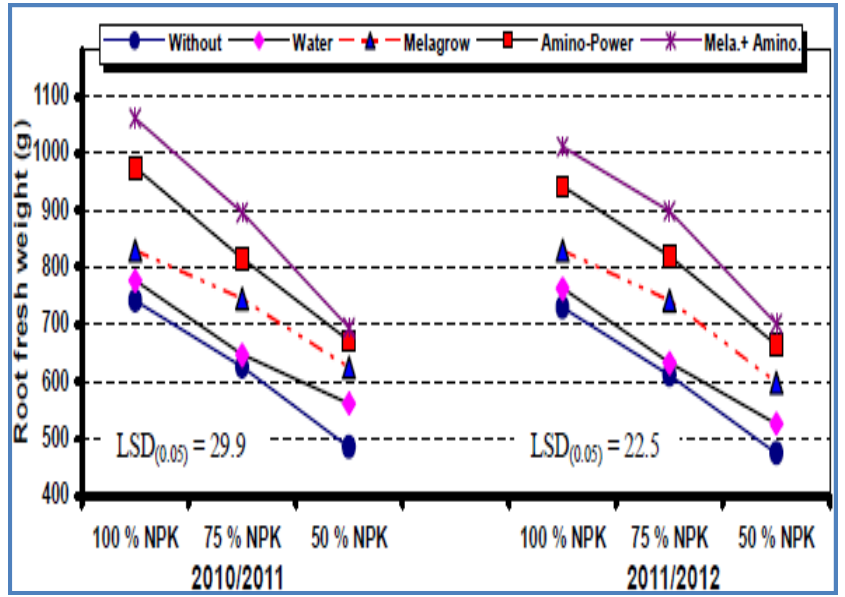

Fig. 3- Root fresh weight (g) of sugar beet as affected by the interaction between NPK levels and foliar fertilization treatments during 2010/2011 and 2011/2012 seasons.

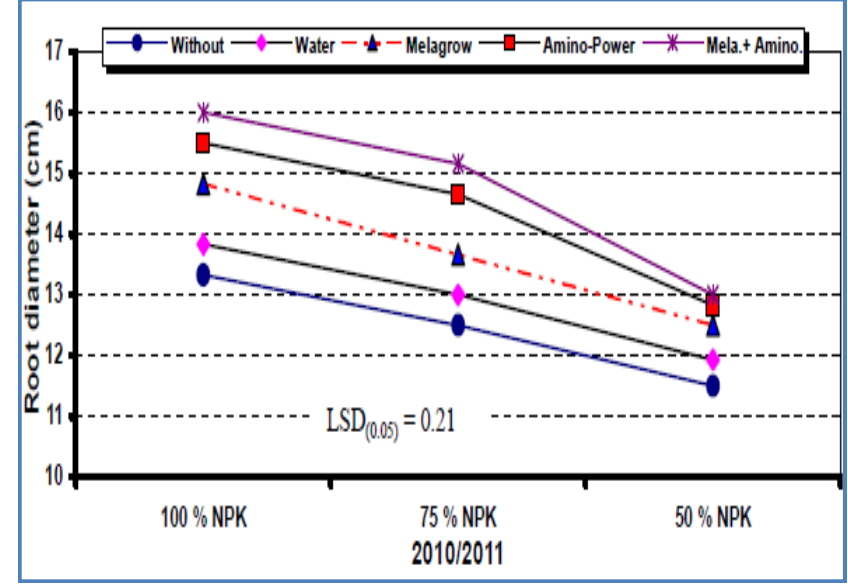

Fig. 4- Root diameter $(\mathrm{cm})$ of sugar beet as affected by the interaction between NPK levels and foliar fertilization treatments during 2010/2011 season

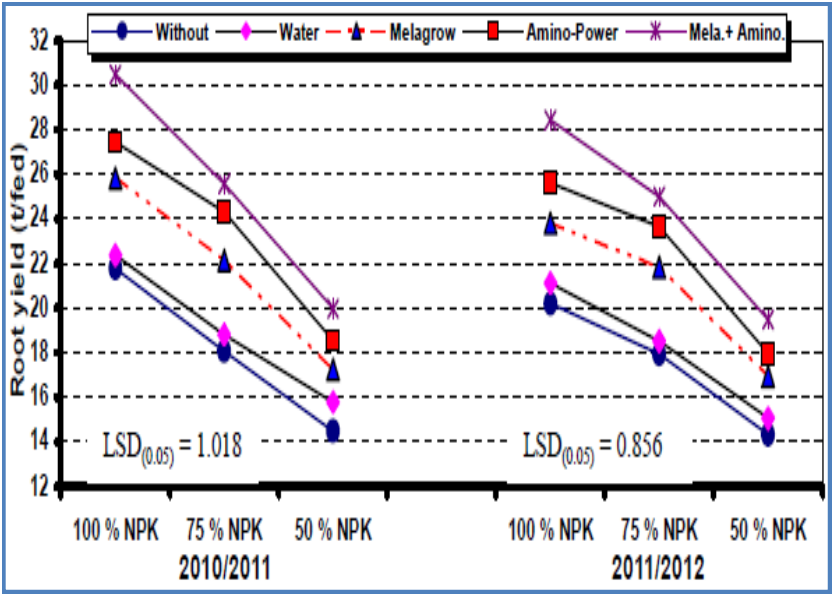

Fig. 5- Root yield (t/fed) of sugar beet as affected by the interaction between NPK levels and foliar fertilization treatments during 2010/2011 and 2011/2012 seasons.

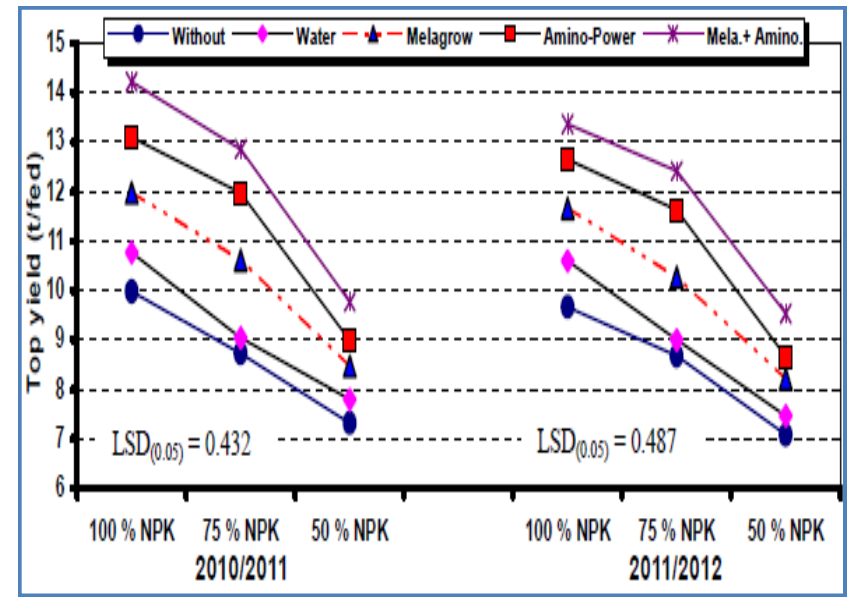

Fig. 6- Top yield (t/fed) of sugar beet as affected by the interaction between NPK levels and foliar fertilization treatments during 2010/2011 and 2011/2012 seasons.

Accordingly, the favorable treatment that increased sugar beet yields and quality parameters in the same time reduces agriculture 
costs and environmental pollution was mineral fertilizing sugar beet plants with $75 \%$ of the recommended level of NPK and foliar spraying with the mixture of Melagrow + Amino-Power.

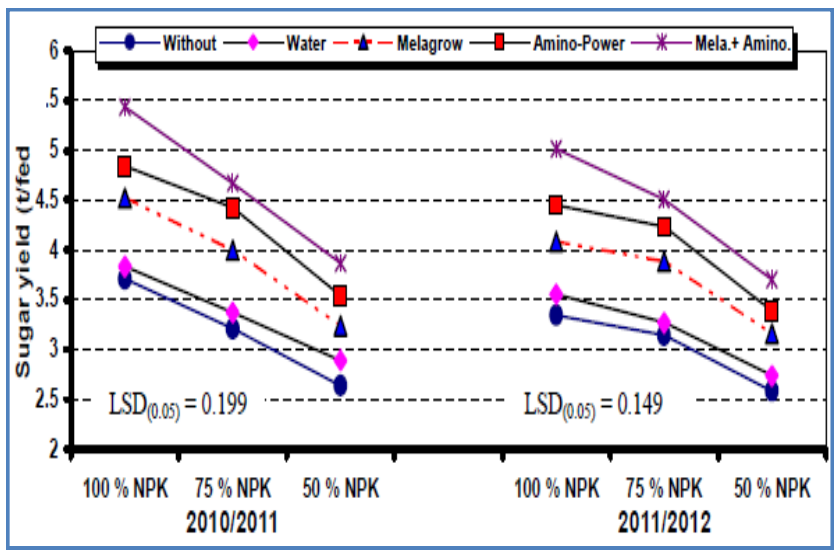

Fig. 7- Sugar yield ( $\mathrm{t} / \mathrm{fed}$ ) of sugar beet as affected by the interaction between NPK levels and foliar fertilization treatments during 2010/2011 and 2011/2012 seasons.

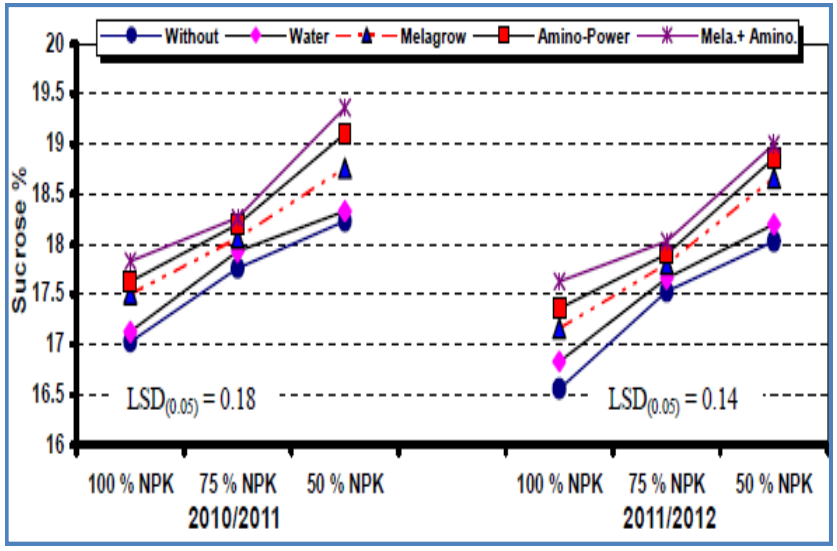

Fig. 8- Sucrose $\%$ of sugar beet as affected by the interaction between NPK levels and foliar fertilization treatments during 2010/2011 and 2011/2012 seasons.

\section{Conclusion}

Maximum sugar beet growth, yields and its components were achieved by mineral fertilizing with $100 \%$ of the recommended level of NPK ( $80 \mathrm{~kg} \mathrm{~N}+30 \mathrm{~kg} \mathrm{P} \mathrm{O}_{5}+48 \mathrm{~kg} \mathrm{~K} \mathrm{O}_{2} / \mathrm{fed}$ ) and foliar spraying with the mixture of Melagrow + Amino-Power twice after 50 and 70 days from sowing. To reduce agriculture inputs and environmental pollution, it could be recommended that mineral fertilizing with $75 \%$ of the recommended level of NPK $\left(60 \mathrm{~kg} \mathrm{~N}+22.5 \mathrm{~kg} \mathrm{P} \mathrm{O}_{5}+36 \mathrm{~kg}\right.$ $\mathrm{K}_{2} \mathrm{O} / \mathrm{fed}$ ) and foliar spraying with the mixture of Melagrow + AminoPower, increased yields and quality upon mineral fertilizing with $100 \%$ of the recommended level of NPK + without spraying.

\section{References}

[1] Abdel-Motagally F.M.F. and Attia K.K. (2009) Int. J. Agric. Biol., 11(6), 965-700.

[2] Abou El-Nour E.A.A. (2002) Pak. J. Bio. Sci., 5(3), 259-262.

[3] Amer M.A., Attalah M.Z., Ibrahim M.F. and El-Taweel F. (2004) J. Agric. Sci., Mansoura Univ., 29(6), 2963-2978.
[4] Attia A.N.E., Badawi M.A., Seadh S.E. and El-Hety S.M.S. (2011) J. Plant Production, 2(12), 1703-1716.

[5] Carruthers A. and Oldfield J.F.T. (1960) Int. Sugar J., 63, 7274.

[6] Diána U. and Győri Z. (2007) Analele Universităţii din Oradea, Fascicula: Protecţia Mediului, XII, 187-192.

[7] Draycott A.P. (1993) Nutrition, The Sugar Beet Crop., 238-277.

[8] El-Geddawy I.H., El-Shafai A.M.A. and Azzazy N.B. (2006) J. Agric. Sci. Mansoura Univ., 31(1), 43-54.

[9] Gobarah Mirvat E., Mekki B.B., Mohamed Magda H. and Eawfik M.M. (2011) American-Eurasian J. Agric. \& Environ. Sci., 10(4), 626-632.

[10]Gomaa A.M., Freweez H. and Abo-El-Wafa A.M. (2005) Assiut J. of Agric. Sci., 36(3), 39-56.

[11]Gomez K.N. and Gomez A.A. (1984) Statistical Procedures for Agricultural Research., 2nd ed., 95-109.

[12]Grzebisz W., Przygocka Cyna K., Lukowiak R. and Biber M. (2010) J. Elementol, 15(3), 493-507.

[13]Kandil A.A., Badawi M.A., El-Moursy S.A. and Abdou U.M.A. (2002) J. Agric. Sci. Mansoura Univ., 27(11), 7257-7266.

[14]Kowalczyk K. and Zielony T. (2008) Conf. of Biostimulators in Modern Agriculture, Warsaw, Poland.

[15]Leilah A.A., et al. (2007) Sci. J. of King Faisal Uni., 8(1), 87100.

[16]Marinkovic B., Crnobarac J., Jaćimović G., Marinković D., Mircov D.V. and Rajici M. (2008) J. of Agri. Res., 40(2), 99-104.

[17]Monreala J.A., Jiméneza E.T., Remesala E., Morillo-Velardeb R., García-Mauriñoa S. and Echevarríaa C. (2007) Enviro. and Exper. Botany, 60(2), 257-267.

[18]Moore A., Stark J., Brown B. and Hopkins B. (1999) University of Idaho College of Agricultural and life Science, CIS1174, 1-7.

[19]Nemeat Alla E.A.E., Aboushady K.A. and Yousef N.O. (2007) J. Agric. Sci. Mansoura Univ., 32(10), 8069-8078.

[20]Ramadan B.S.H. (2005) J. Agric. Sci. Mansoura Uni., 30(2), 773-783.

[21]Romheld V. and El-Fouly M.M. (1999) 2nd International Workshop on Foliar Fertilization, Bangkok, Thailand, 1-34.

[22]Seadh S.E. (2004) Agricultural Studies on Sugar Beet Crop. Ph.D. Thesis, Fac. of Agric. Mansoura Univ., Egypt.

[23]Seadh S.E., Farouk S. and El-Abady M.I. (2007) African Crop Sci. Conf., 8, 147-153.

[24]Seadh S.E. (2008) Meeting the Challenges of Sugar Crop \& Integrated Industries in Developing Countries, Egypt, 110-115.

[25]Sims A.L. and Smith L.J. (2001) J. of Sugar Beet Res., 38(1), 1 $-17$.

[26]Snedecor G.W. and Cochran W.G. (1980) Statistical Methods. 7th ed., USA.

[27]Tugnoli V. and Bettini G. (2003) 1st Joint IIRB-ASSBT Congress, San Antonio, USA, 655-660. 